RESEARCH ARTICLE

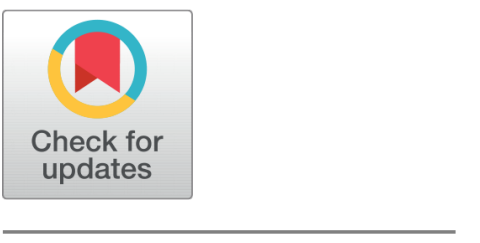

G OPEN ACCESS

Received: 23-04-2020

Accepted: 16-06-2020

Published: 09-07-2020

Editor: Dr. Natarajan Gajendran

Citation: Saeed MU, Bilal MZ, Raza MR (2020) Political speeches and media agenda: electoral rigging movement -2013 as a building factor of media agenda in Pakistan. Indian Journal of Science and Technology 13(24): 2436-2445. https ://doi.org/10.17485/IJST/v13i24.387

* Corresponding author. Muhammad Usman Saeed

School of Media \& Communication Studies, University of Central Punjab, Lahore, Pakistan usman841@yahoo.com

Funding: None

Competing Interests: None

Copyright: (c) 2020 Saeed, Bilal, Raza. This is an open access article distributed under the terms of the Creative Commons Attribution License, which permits unrestricted use, distribution, and reproduction in any medium, provided the original author and source are credited.

Published By Indian Society for Education and Environment (iSee)

\section{Political speeches and media agenda: electoral rigging movement - 2013 as a building factor of media agenda in Pakistan}

\author{
Muhammad Usman Saeed ${ }^{1 *}$, Muhammad Zahid Bilal' ${ }^{2}$, \\ Muhammad Riaz Raza ${ }^{3}$
}

1 School of Media \& Communication Studies, University of Central Punjab, Lahore, Pakistan 2 Department of Media and Communication, University of Okara, Punjab, Pakistan

3 Department of Media Studies, Bahria University, Islamabad, Pakistan

\section{Abstract}

Objectives: To explore the relationship of Pakistani Political Leader Imran Khan Speeches and newspapers agenda examining the coverage of electoral rigging issue which gained the momentum of a movement in Pakistan during post elections 2013 against the then siting government of Pakistan Muslim League Nawaz's (PML-N). Method: The study takes its roots from the network agenda setting model. It aims to study the model in the context of agenda building in Pakistan. Social Network Analysis technique was used to analyze the data collected from two sources including: Live speeches of movement leader, Imran Khan and coverage of three leading Urdu dailies of Pakistan; Express, Dunya and Jang to explore the relationship among these agenda setting networks. Firstly, we performed content analysis of 128 speeches of Imran Khan, 964 news stories and 239 editorials of sample newspapers. Secondly, we turned data into matrices and applied network analysis techniques with the help of UCINet and NetDraw software. Findings: QAP Correlation indicates strong association among, Imran Khan Speeches and newspapers agenda. However, these associations are different for two issues; Electoral rigging, and PML-N rigging. Imran Khan influenced the media agenda more for shaping the image of elections-2013 as unfair and rigged. On the other hand, his speeches were found less influential in shaping media agenda about the involvement of PML-N in electoral rigging. In this way, study reveals that third level agenda building effects depend upon the political nature of issues.

Keywords: Third level agenda building; political speeches; electoral rigging; Pakistan elections-2013; social network analysis 


\section{Introduction}

Role of mass media in the presentation of political issues and objects and its perception among the audience has been central among the agenda setting scholars for last four decades starting from the ground breaking Chappell Hill study in $1968^{(1-3)}$. The traditional or first level of agenda setting studied agenda as a set of objects and issues ${ }^{(4-8)}$. Where, the objects are public issues, but they could be other items or topics, such as the agenda of political candidates during an election ${ }^{(9)}$. Later on, this scholarship turned the focus from object agenda to attribute agenda. In other words, from first level to second level of agenda setting ${ }^{(10-14)}$. For each object on the agenda, there is an agenda of attributes that influences our understanding of the object ${ }^{(9)}$.

A recent development in Agenda Setting research is Network Agenda Setting Model proposed by Guo \& McCombs in 2012. This model asserts that "the salience of the network relationships among objects and/or attributes, in addition to the rank-order of individual elements, can also be transferred from the media to the public". This expanded perspective on the bundling of objects and attributes has been termed as third level of agenda setting ${ }^{(15-20)}$. Network agenda setting as a third level approach need to be studied more extensively to extend this mode of scholarship as it seems more innovative. Agenda building is also an important domain of study for this emerging agenda setting research ${ }^{(4,12,13,21-28)}$. Kiousis, Kim ${ }^{(29)}$ studied the agenda building at network level and found that media network agenda can also be built by political actors. Therefore, this model was used to study the role of Pakistani politicians for influencing media agenda.

Present study takes roots from Agenda setting theory. Scholars in Pakistan, have also explored different aspects of agenda setting theory ${ }^{(30-35)}$. However, this study is going to test Network Agenda Setting Model proposed by Guo \& McCombs in 2012. To date, not a single study is found on NAS model in Pakistan. So, this study will provide opportunities for Pakistani scholars to test new dimensions of agenda setting in Pakistan.

\subsection{Pakistan Elections - 2013 \& Electoral Rigging Movement}

Elections - 2013 were considered very important in Pakistan's democratic process. Because it was first time in history that a democratic elected government completed his tenure and power was transferred through democratic process according to constitution of Pakistan. In Elections 2013, a record voter turnout was seen. Overall voter turnout was 53-55\% in which overall gain was $34 \%{ }^{(36)}$. The report of European Union Elections Observation Mission also declared these Elections-2013 more democratic than previous elections ${ }^{(37)}$. Pakistan Muslim League Nawaz (PML-N) got supreme majority in these elections and formed government in center. On the other side, Pakistan Tehreek-i-Insaf (PTI) showed reservations on elections conduct. PTI Chairman Imran Khan blamed PML-N for rigging in elections. They continuously kept challenging elections-2013 results at different forums and staged protests against the conduct of election and calling it rigged elections of Pakistan's history. In politics of Pakistan, leaders and political parties often prefer street politics, slogans and processions to parliamentary sessions. In this context of post elections-2013, these strategies were also used to gain public opinion ${ }^{(38)}$. These protests and blames against electoral rigging eventually came up with movement advanced toward Islamabad, the capital of Pakistan.

On $11^{\text {th }}$ May, 2014, PTI organized a political procession at D-Chowk, Islamabad and launched a movement against alleged rigging in Elections-2013. After this procession, PTI started to show his power at different cities of country. $14^{\text {th }}$ August, 2014 saw unprecedented movements in Pakistani politics. Pakistan Awami Tehrik (PAT) started "Inqalab March" (Revolution March) \& PTI started "Azadi March" (Independence March) towards Islamabad. A large number of public followed them. After reaching Islamabad, the parties decided to stage sit-in Islamabad, for the fulfillment of their demands. PAT ended Sit-In, on $21^{\text {st }}$ October, 2014, and PTI Sit-in was ended on $17^{\text {th }}$ December, 2014 after a brutal terrorist attack Army Public School, Peshawar.

This movement against electoral rigging, left serious effects on Pakistani Politics. Movement resulted in the formation of Judicial Commission for investigations alleged electoral rigging during Elections-2013. On April 03, 2015, President Mamnoon Hussain issued an ordinance for the formation of Judicial Commission. On April 08, 2015 Chief Justice Nasir-ul-Mulk formed a 3 members' judicial commission. Commission was headed by Chief Justice Nasir-ul-Maulk, while the other two members were; Justice Ameer Hani Muslim and Justice Afzal Khan. This was unprecedented that accountability of elections happened first time in Pakistani political history. The three-member judicial commission initiated its proceedings on April 9, 2015 and concluded his final report on July 03, 2015. The report said that there were irregularities to the extent of the Election Commission but they did not constitute a reflection of a deviation from the public mandate ${ }^{(39)}$

During elections and post elections context of Pakistan, media and journalists are often used for electioneering. Politicians use media for blame gaming on rival political parties. Not only politicians but other state actors also use media to build public opinion towards elections and their outcomes ${ }^{(40)}$. During this movement, Imran Khan, Chairman PTI, delivered more than 130 speeches, out of which, 128 were live broadcasted by different news channels of Pakistan. As McNair noted that "Political speeches, delivered in the pseudo-event environment, attempt to satisfy the journalists' need for easily reportable 'bits' of political information, in such a way as to set the news agenda in the politicians' favor" ${ }^{\prime 41)}$. It is also argued that information 
subsidies - press releases, statements, conferences and "news commercialization" etc - have tremendous inputs into media content $^{(24)}$. During elections, political speeches are used to promote political causes and to gain public confidence ${ }^{(42)}$. Therefore, these speeches are an important source of study the agenda building. Present study attempts to measure the influence of these speeches on media agenda about electoral rigging issue. Further, it also explores the relationship of political agenda on media agenda about PML rigging issue. Here, PML-N rigging has been taken as planned rigging by PML-N government. While, electoral rigging shows the general rigging in elections-2013.

\section{Hypotheses}

Agenda setting is continuously evolving from one dimension to another ${ }^{(43)}$. Agenda building is one of them. On the contrary to agenda setting, agenda building seeks to answer, who sets media agenda? ${ }^{(21,23)}$. Agenda building refers to the process by which news organizations and journalists feature, emphasize, and/or select certain events, issues, or sources to cover over others $^{(44)}$. Apart from the transferal of issue or object salience to the public, scholars have studied influences on news media agendas, ${ }^{(4,12,13,22,24-28)}$.

Scholars found different influences on media agenda such as political elites, other media sources, and norms and traditions of society ${ }^{(45)}$. Shoemaker and Reese included media routines, organizational sociology, ideology, and individual differences among journalists has tremendous input in media agenda ${ }^{(46)}$. Real world indicators also influence media agenda ${ }^{(4)}$. As agenda setting is studied at object and attribute level, similarly agenda building also have been studied at object and attribute level. Other than, first and second level agenda building, there is also an evidence for third level agenda building ${ }^{(29)}$. In sum, Agenda building is the study of factors which contributes in shaping media agenda. $\mathrm{H} 1$ of study takes roots from agenda-building perspective. Keeping in view with existing literature, following statements are hypothesized.

H1: Political agenda of electoral rigging in Imran Khan Speeches will positively associate with the agenda of media mews stories and editorials.

H2: Political agenda of PML-N rigging in Imran Khan Speeches will positively associate with the agenda of media news stories \& editorials.

\section{Methods \& Measures}

Research design of present study was based on triangulation of methods. Present study was conducted in three stages. Firstly, PTI Political agenda about electoral rigging and PML-N rigging was measured by analyzing 128 speeches of Imran Khan. Secondly, media agenda was measured by (a) analyzing news stories related to elections-2013 on front \& back pages of three leading Urdu Newspapers; Daily Express, Daily Dunya and Daily Jang from $11^{\text {th }}$ May, 2014 to $17^{\text {th }}$ December, 2014 (N=964). (b) By analyzing editorials of these newspapers related to elections-2013 during the same period ( $\mathrm{N}=239)$.

\subsection{Content Analysis of Imran Khan Speeches}

Imran Khan speeches provide enormous reason to study political agenda of PTI. Systematic randomly selected ten speeches were analyzed qualitatively for defining coding categories. For this purpose, all speeches were ordered chronologically, and then $33^{\text {rd }}$ speech was randomly selected, then every $12^{\text {th }}$ speech was selected from $33^{\text {rd }}$ speech to onward. All speeches were downloaded from internet video sites like tune.pk, \& dailymotion etc. By applying Holsti's formula ${ }^{(47)}$, intercoder reliability (between two coders) at this stage was 0.9 .

\subsection{Measures}

For analyzing speeches, content sheet was formed. In social network analysis, unit of analysis is dyad: A combination of two ties and their relational ties. In order to measure connections and their relational ties, a set of six elements was constructed for Elections-2013; Rigging, Accountability, Returning Officers, Corruption, Four Constituencies, \& Election Commission (Annexure - I) and six elements were constructed for PML-N; Family Politics, Injustice, Go Nawaz Go, Corruption, Accountability, \& Rigging (Annexure - II). Systematic randomly selected ten speeches were analyzed qualitatively for defining coding categories. For this purpose, all speeches were ordered chronologically, and then $33^{\text {rd }}$ speech was randomly selected, then every $12^{\text {th }}$ speech was selected from $33^{\text {rd }}$ speech to onward. All speeches were downloaded from internet video sites like tune.pk, \& dailymotion etc. By applying Holsti's formula ${ }^{(47)}$, intercoder reliability (between two coders) at this stage was 0.9 . 


\subsection{Content Analysis of Newspapers}

Firstly, in this stage, universe of the study was Urdu Newspapers of Pakistan. Three leading papers were selected; Daily Jang, Daily Dunya, Daily Express from $11^{\text {th }}$ May, 2014 to $17^{\text {th }}$ December, $2014(\mathrm{~N}=654)$. Further, only front and back pages were selected as sample. Unit of analysis was news stories related to Elections-2013. Categories and their relational ties were coded as same as in the $1^{\text {st }}$ step of content analysis. Pilot study was done on 10 newspapers. Intercoder reliability between two coders was obtained as 0.85 by using Holsti's formula.

Secondly, the universe, sample newspapers, and time was same. However, this time, unit of analysis was editorial related to Elections-2013. Two hundred and thirty nine editorials were coded in this step with predefined categories and their relational ties scheme in $1^{\text {st }}$ stage. Pilot study was conducted on 10 editorials. Intercoder reliability between two coders was 0.80 by using Holsti's formula ${ }^{(47)}$

\section{Results}

After data collection, according to the nature of study, and predefined categories of elements, matrices containing 6 rows \& 6 columns were created about Elections-2013 and 6 rows \& 6 column matrices were created for PML-N government. UCInet \& NetDraw was used, for data analysis. Quadratic Assignment Procedure (QAP) Correlation test was applied to symmetrical matrix data. In making results more accurate and reliable, matrices datasets were randomly permuted during QAP correlation test.

Findings show that total 128 speeches of Imran Khan were live broadcasted in mainstream news channels of Pakistan from May, 2014 to December, 2014 (3\%, 2\%, 2\%, 16\%, 23\%, 23\%, 21\%, and 11\% respectively). Most of the speeches (35\%) were broadcasted for 16 to 30 minutes (Below $15 \mathrm{~min}, 27 \%$; 31-45 min, 29\%; and above $45 \mathrm{~min}, 9 \%$ ). In addition to, (29\%) speeches had duration 31 to 45 minutes. Furthermore, findings highlight that the issue of electoral rigging gained much attention of Pakistani print media. Three leading Urdu dailies gave high coverage to this issue. Daily Dunya presented more stories (347) than other two dailies; Express (324), Jang (293). Moreover, the issue was also much highlighted in editorials of three dailies; Dunya (93), Express (53) and Jang (93).

\subsection{Network Agenda Building}

This study finds empirical evidence for supporting NAB. However, the effects were only observed for electoral rigging issue. Figures 1, 2 and 3 show that the major focus of

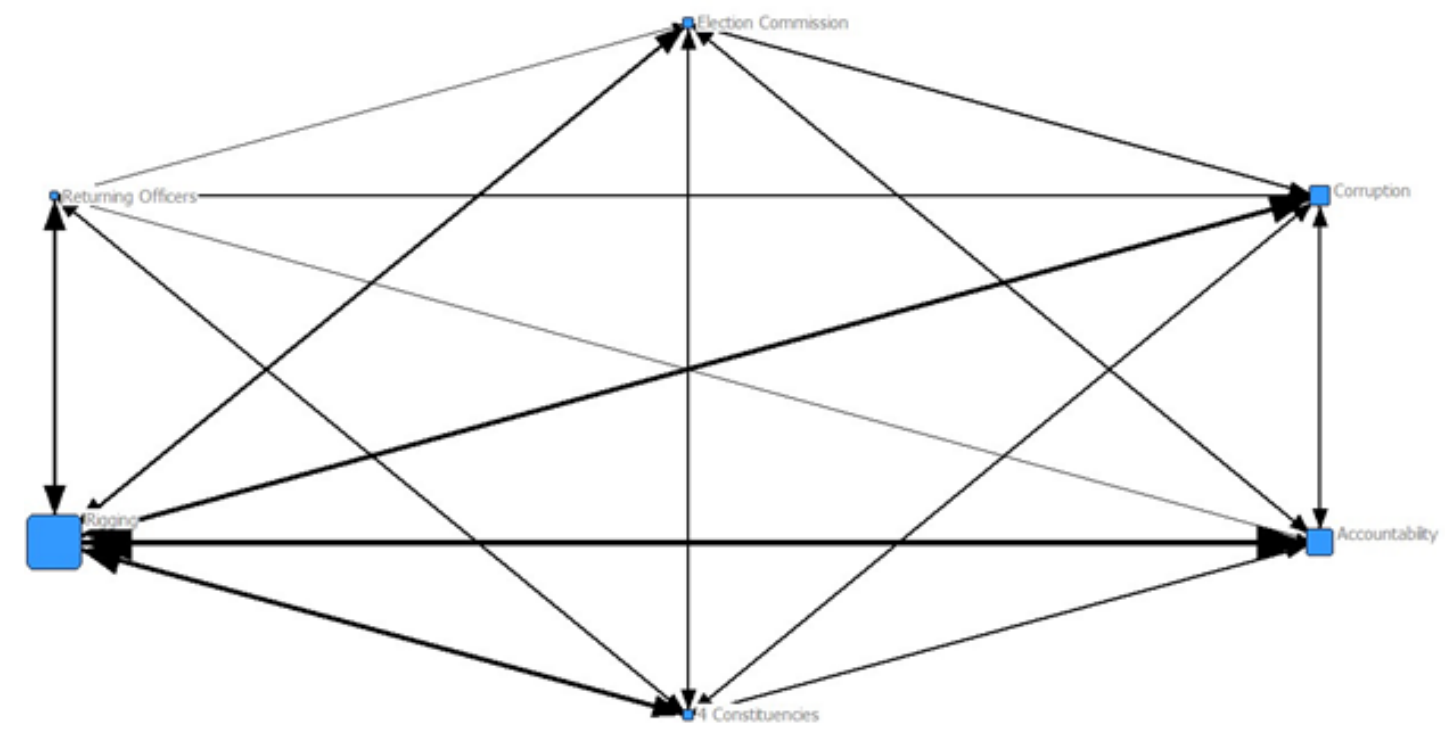

Fig 1. Imran Khan Network Agenda about Electoral Rigging ( $=128)$ 


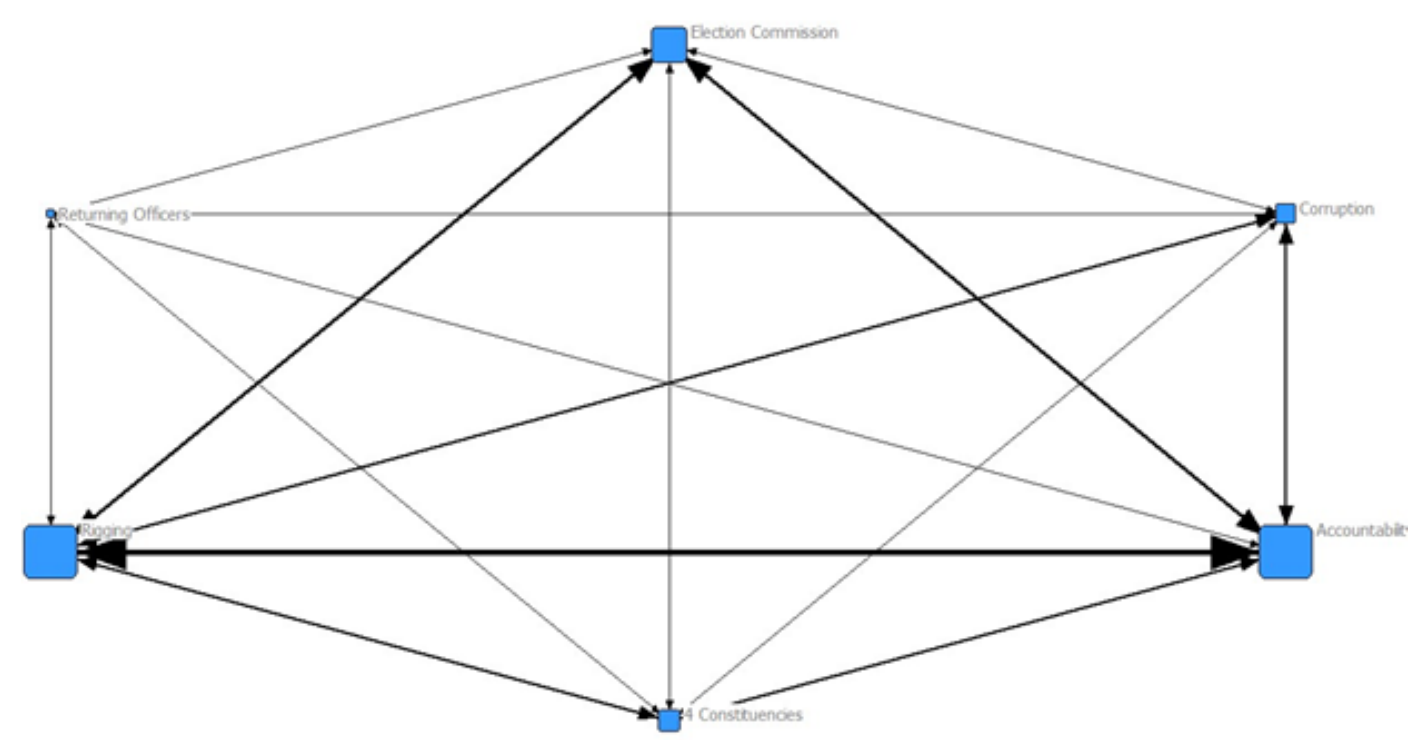

Fig 2. Media Network Agenda of Electoral Rigging based on News Stories of three Urdu Dailies (N=964)

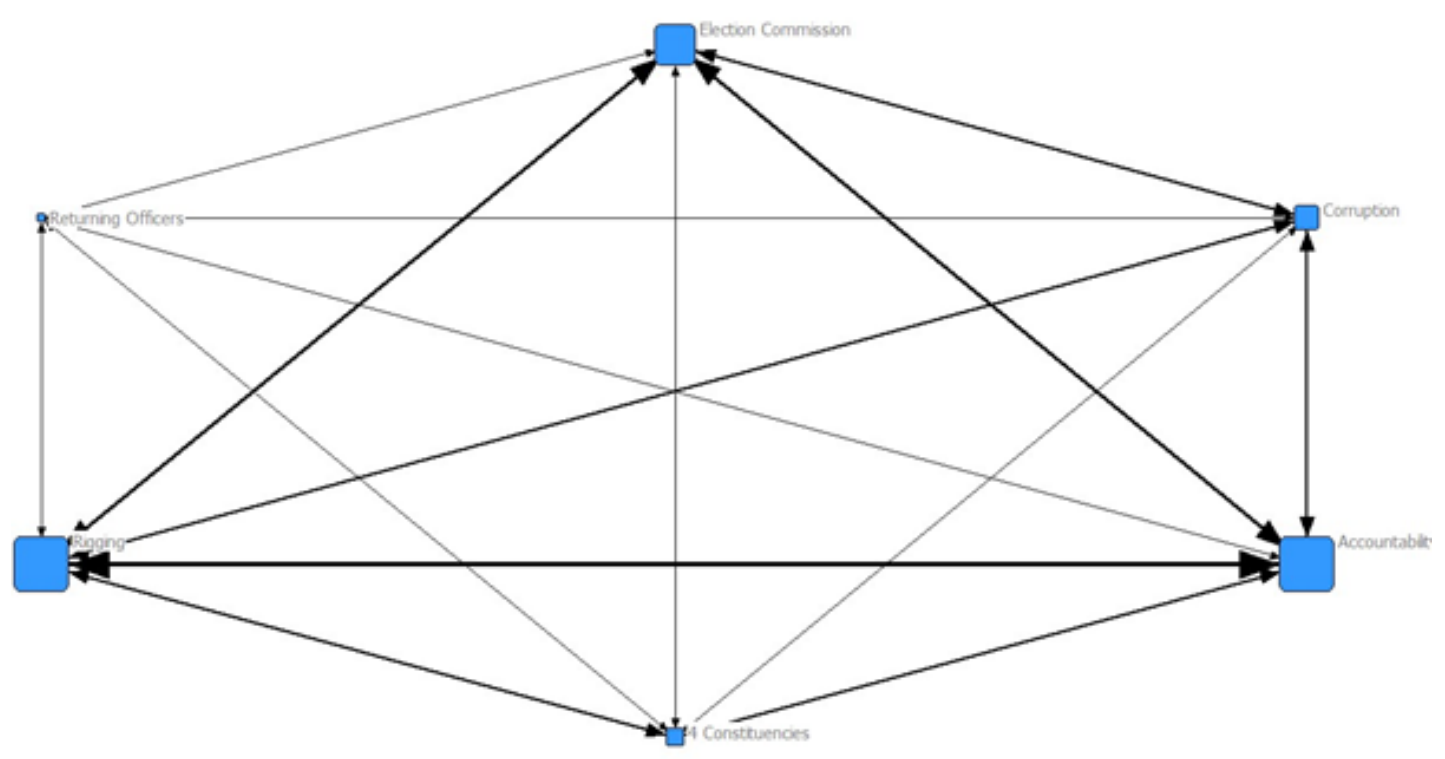

Fig 3. Media Network Agenda of Electoral Rigging based on Editorials of three Urdu Dailies $(\mathrm{N}=239)$

Imran Khan, and newspapers' stories and editorials has quite a similarity. Rigging and accountability were much emphasized by Imran Khan and media. These two elements have more ties than any other elements. However, in media agenda, it can be clearly viewed that election commission is also a prominent element. It also has considerable ties with both; rigging and accountability. Furthermore, QAP correlation values among Imran Khan Agenda and Newspapers' news stories and editorials show significant associations among political agenda and media agenda ( Table 1).

On the other hand, NAB effects are quite limited in case of PML-N rigging. Imran Khan excessively focused on corruption and resign of Prime Minister ( Figure 4). 


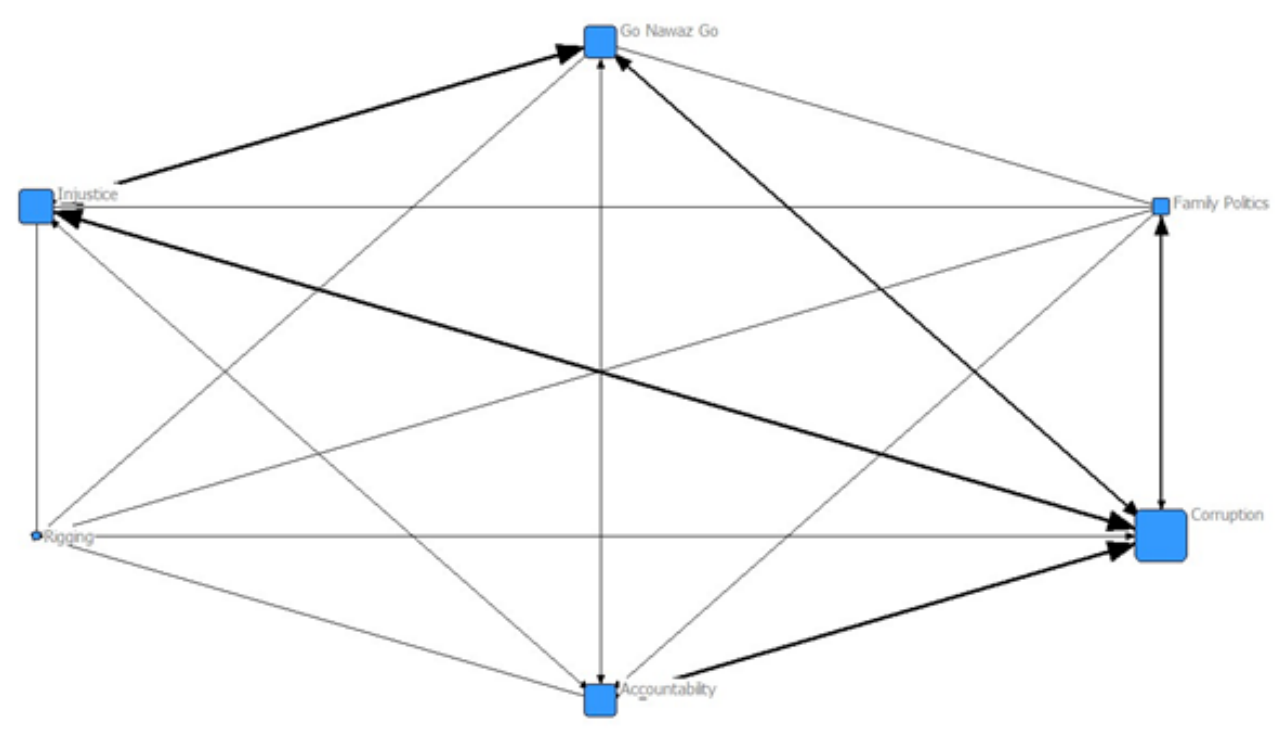

Fig 4. Imran Khan Network Agenda about PML-N Rigging ( $\mathrm{N}=128)$

However, media agenda in news stories and editorials seems different. Although, news coverage of three leading papers ( Figure 5), shows some similarity with Imran Khan agenda,

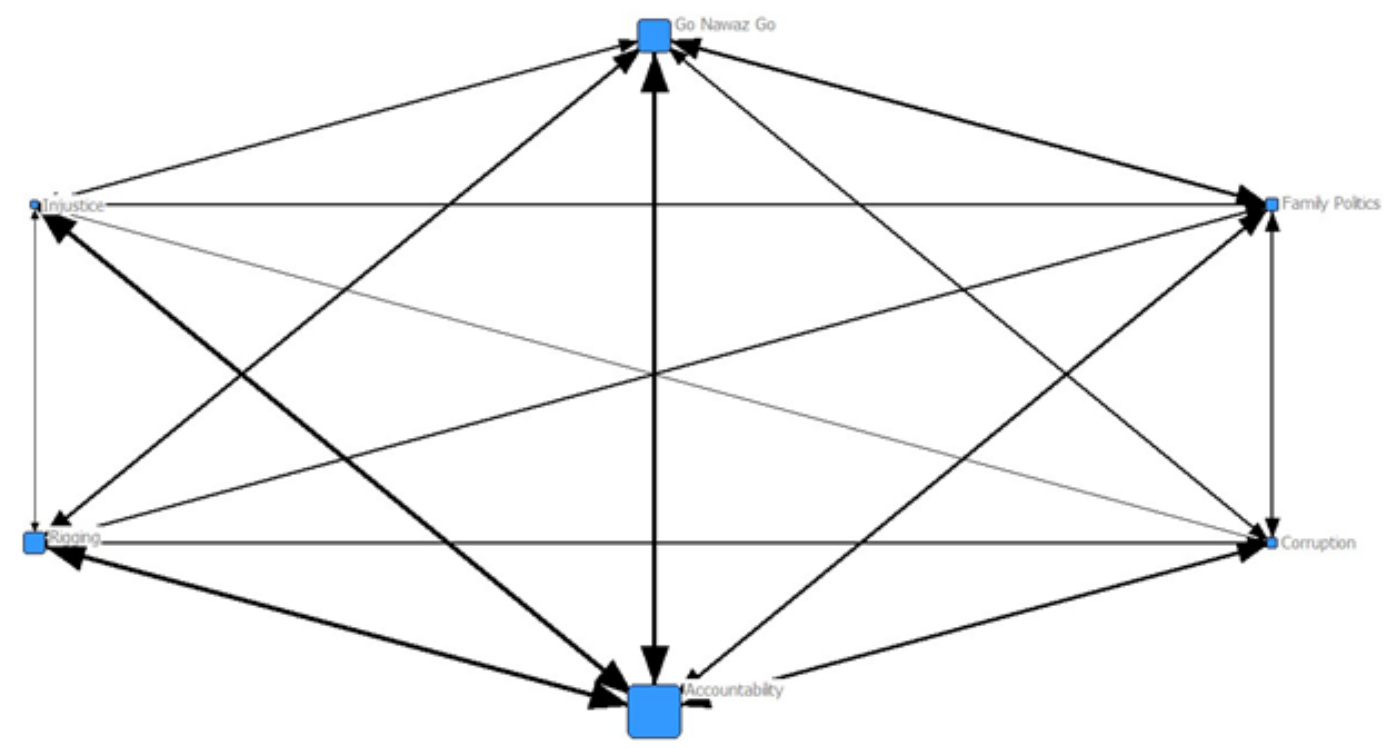

Fig 5. Media Network Agenda about PML-N Rigging based on News Stories of three Urdu Dailies (N=964)

yet editorials policy of three papers is quite different from Imran Khan agenda ( Figure 6).

Insignificant correlations among agenda of Imran Khan, news stories and editorials provide evidence for limited effects of political agenda on media agenda ( Table 1). 


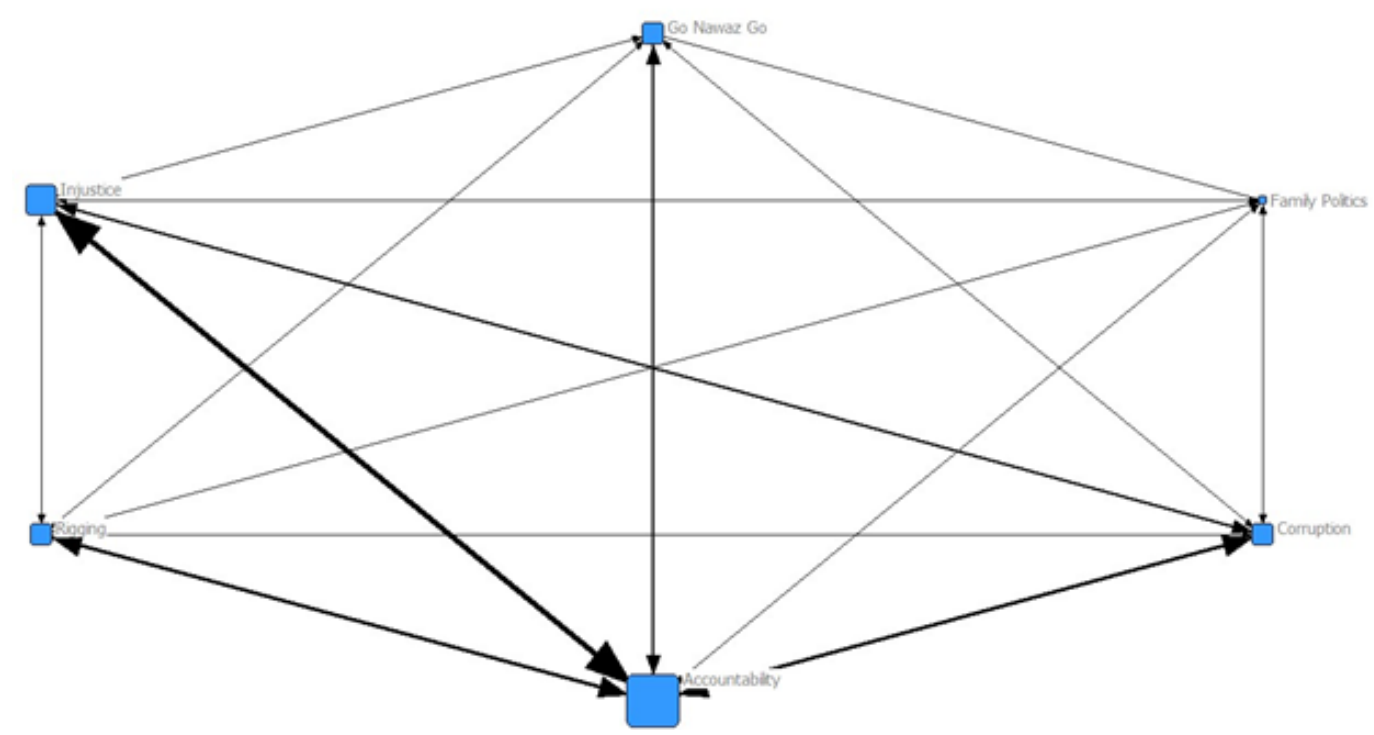

Fig 6. Media Network Agenda about PML-N Rigging based on Editorials of three Urdu Dailies (N=239)

\section{Discussion}

Pakistan is a country, where democracy is in its infancy. In its 68 years of independence, it observed three long martial law rules. However, now democracy roots are becoming strong in Pakistan. After 2002 general elections, power is being transferred only through electoral system. General elections- 2013 were considered very important for the political history of the country. In these elections PML-N got supreme majority in federal and Punjab province. On the other side, PTI emerged as second largest political party in the country. Soon after the conductions of elections, PTI blamed PML-N for electoral rigging and theft of public mandate. PTI strongly protested against electoral rigging in elections tribunals, Supreme Court and finally in street protests.

During this political movement against electoral rigging, media coverage was seemed very helpful for promoting PTI cause. All newspapers, and mainstream media gave excessive coverage to PTI processions, conferences and tweets. Issue of electoral rigging was observed to discuss in columns, editorials and media talk shows very much. Present study was based to examine the role of political speeches in promoting electoral rigging issue among media agenda. For examining this role of media in political communication, framework of agenda setting theory was used. The recent work of Guo \& McCombs ${ }^{(15,16)}$ has turned the focus of agenda setting research towards third level of theory, Netwrok Agenda Setting Model ${ }^{(17)}$.

Findings of the study ( Table 1) demonstrate strong influence of Imran Khan's network agenda about electoral rigging over editorials' agenda of three dailies $(\mathrm{r}=0.655, \mathrm{p}=0.027)$. Furthermore, QAP correlation value of 0.666 shows strong association between elements associations in Imran Khan Speeches and news stories of three dailies. This correlation is significant at 0.03 level ( Table 1). These results support Kiousis, Kim ${ }^{(29)}$ findings about network agenda building. They found Campaign blog posts, press releases, and issue platforms appeared to be the most effective agenda-building tools at network level. This study further adds political speeches as an effective element in media agenda building at network level, supporting the argument that political speeches are influential for building media agenda ${ }^{(24)},{ }^{(41)}$. These findings also relates with the previous works on agenda building at object level ${ }^{(4,22,24,25,27,48,49)}$ and attribute level ${ }^{(12,13,25,48)}$. Hence, findings provide support for $\mathbf{H 1}$ that political agenda of electoral rigging in Imran Khan Speeches positively associates with the agenda of media news stories and editorials. These findings encouraged researcher to argue that politicians can build media agenda in Pakistan. Political speeches, processions and conferences, which are broadcasted live on mainstream media are an effective tool for gaining media attention towards specific political cause.

On the other hand, Imran Khan agenda about PML-N rigging don't relate with newspapers' editorials, nor with news stories' agenda ( Table 1). 
Table 1. QAP Correlationsabout Electoral Rigging and PML-N Rigging among Imran Khan Agenda, Media Agenda \& Public Agenda

\begin{tabular}{lllll}
\hline & Electoral Rigging Issue & & PML-N Rigging Issue \\
& Media Editorials Agenda & Media News Stories Agenda & Media Editorials Agenda & Media News Stories Agenda \\
Political Agenda & $\mathrm{r}=0.655^{*}$ & $\mathrm{r}=0.666^{*}$ & $\mathrm{r}=0.358$ & $\mathrm{r}=-0.026$ \\
& $\mathrm{p}=0.027$ & $\mathrm{p}=0.039$ & $\mathrm{p}=0.221$ & $\mathrm{p}=0.484$ \\
\hline
\end{tabular}

*. QAP Correlation is significant at the 0.01 level.

Note: In Figure 1-6, Symbol size represents, the frequency of element and line thickness represents, ties between two connected elements.

Reasons of this contradiction might be considered the political communications of PML-N. During content analysis, heavy political advertising by PML-N was observed. So, it might be a reason for this contradiction. Moreover, Imran Khan clearly blames Chief Editor of Daily Jang, Mir Shakeel-ur-Rahman for electoral rigging. So, Daily Jang agenda was totally opposite to Imran Khan Agenda. It might be a factor for this contradiction. As Shoemaker and Reese ${ }^{(46)}$ argued that media routines, organizational sociology (both internal and external to news organizations), and ideology, all in addition to individual differences among journalists effects news agenda. Similarly, there is also an evidence that media agenda building by politicians depends on different conditions, including nature of issues ${ }^{(5)}$. Therefore, $\mathbf{H} \mathbf{2}$ that political agenda of PML-N rigging in Imran Khan Speeches will positively associate with the agenda of media news stories and editorials is disapproved. So, it is argued that although politicians can divert media agenda towards their interests, yet the media is not much passive. Media also has its own agenda. On political issues, it exerts its own influence, rather than simply conveying politicians' agenda.

These findings make a claim that media in Pakistan is very active and has significant influence on public perceptions of issues. It can be used for gaining positive political objectives for democratic development of country. However, it also shows the negative aspect of the picture, that media can also be used for negative political purposes. And for attaining negative aims, live speeches can exert significant influence on public minds. Therefore, state should work actively to monitor live speeches. Otherwise, it may harm national sovereignty. These speeches and media influence should not be underestimated.

Present study shows although media disagreed or against the views of specific political party, yet the news coverage of political activities can be gained through staging political events and live political speeches. These speeches and events increase newsworthiness and then media has to report it due to respect of news values. Media gave coverage to Imran Khan speeches. It influenced public perception towards electoral rigging, however, media did not support the PTI cause of PML-N rigging and $\mathrm{PM}$ resignation.

That's why, PTI demand for judicial investigations of electoral rigging was fulfilled with the formation of judicial commission headed by Chief Justice Nasir-ul-Mulk. To date of writing, this Judicial Commission (2015) has published his final inquiry report. This report rejected all three allegations of PTI about electoral rigging. These three main allegations of the PTI were included; organized rigging in the 2013 general elections, non-transparent polling and theft of the public mandate. It is also noteworthy, that soon after the elections-2013, Gallup Pakistan Report ${ }^{(36)}$ and EU Elections Observation Mission Report ${ }^{(37)}$ declared Elections-2013 free and fair and more democratic than previous elections. Despite the accuracy, elections2013 were made suspected and rigged in the media agenda and public agenda by PTI. It shows the power of live political speeches of PTI chairman, Imran Khan. Media widely associated element of rigging with elections-2013. It can be viewed as the success of Political communication of Imran Khan.

On the other hand, PTI had to withdraw from the demand of Prime Minister Resignation, because he failed to influence media agenda about PML-N government. Media did not follow Imran Khan agenda against PML-N government. Hence, public perception about PML-N rigging did not change. PML-N is the major political party of country. It has millions of workers and voters in the country. That's why, people rejected the Imran Khan agenda about PML-N. This study explores that importance of political speeches in political events cannot be undermined in Network Agenda Building process. However, these alone are not sufficient to influence media agenda against political parties. Further, it explores that Network Agenda Building is found valid in Pakistan, however, effects depend on nature of issues.

\section{Conclusion}

It is concluded that Imran Khan's live speeches played vital role in influencing media agenda about electoral rigging issue. These speeches made elections-2013 suspected and rigged in the agenda of media. However, these speeches could not influence media agenda about PML-N, due to other factors. These factors include political communication of PML-N for encountering PTI propaganda.

Finally, it is argued, although network agenda building was found valid in Pakistan, yet effects are larger for national issue 
of electoral rigging, and minimal in case of political party, PML-N rigging. Political speeches are very effective in Pakistani context for influencing media agenda. But, these effects depend on other factors including issue nature. On a national issue like electoral rigging, media agenda can be formed by staging political events and speeches. On the other hand, it is very difficult to influence media agenda against a major political party of country.

\section{Limitations of Study}

Although this study attempted to test network agenda building effects in Pakistan. But it should be viewed with several limitations. Firstly, due to time limits, less categories were made about network elements. Secondly, due to theoretical boundaries of Network Agenda Setting, this study don't address the factors of political advertising on media coverage respectively.

\section{For Further Research}

Despite the several limitations, present study provides enormous opportunities for media scholars in Pakistan. It expands network agenda setting research in Pakistan. First of all, future researchers should test this model with more categories of objects, attributes and issues. Furthermore, it should be tested with other related concepts like political advertising for examining a comprehensive picture of Network Agenda Building factors.

\section{References}

1) Graber DA and Smith JM. Political Communication Faces the 21st Century. Journal of Communication. 2005;55(3):479-507. Available from: https: //dx.doi.org/10.1111/j.1460-2466.2005.tb02682.x.

2) Baran S and Davis D. Mass communication theory: Foundations, ferment, and future. Boston: Wadsworth . 2010,. Available from: https://www.amazon. com/Mass-Communication-Theory-Foundations-Journalism/dp/0495898872.

3) Mcquail D. McQuail's mass communication theory. vol. 6. and others, editor. Washington. Sage publications . 2010,.

4) Sheafer T and Weimann G. Agenda Building, Agenda Setting, Priming, Individual Voting Intentions, and the Aggregate Results: An Analysis of Four Israeli Elections. Journal of Communication. 2005;55(2):347-365. Available from: https://dx.doi.org/10.1111/j.1460-2466.2005.tb02676.x.

5) Walgrave $S$, Soroka $S$ and Nuytemans $M$. The mass media's political agenda-setting power: A longitudinal analysis of media, parliament, and government in Belgium. Comparative Political Studies. 1993;41(6):814-836. Available from: https://doi.org/10.1177/0010414006299098.

6) Dunaway J, Branton RP and Abrajano MA. Agenda Setting, Public Opinion, and the Issue of Immigration Reform. Social Science Quarterly. 2010;91(2):359-378. Available from: https://dx.doi.org/10.1111/j.1540-6237.2010.00697.x.

7) Muin MJ. Agenda-setting theory and the role of the media in shaping public opinion for the Iraq war. 2011,. Available from: https://www.semanticscholar. org/paper/Agenda-Setting-Theory-and-the-Role- of-the-Media-in-Muin/1144c7dd6980763b3e068788b567953ca3b2315d.

8) Lee JH and Hahn KT. Factors influencing the agenda-setting effects of newspapers on their subscribers: A multi-level analysis. 233.

9) McCombs M. A Look at Agenda-setting: past, present and future. Journalism Studies. 2005;6(4):543-557. Available from: https://dx.doi.org/10.1080/ 14616700500250438

10) Berdahl L and Soroka SN. Agenda-Setting Dynamics in Canada. Canadian Public Policy / Analyse de Politiques. 2003;29(2):274-274. Available from: https://dx.doi.org/10.2307/3552463.

11) Rill LA and Davis CB. Testing the Second Level of Agenda Setting: Effects of News Frames on Reader-Assigned Attributes of Hezbollah and Israel in the 2006 War in Lebanon. Journalism \& Mass Communication Quarterly. 2008;85(3):609-624. Available from: https://dx.doi.org/10.1177/ 107769900808500308.

12) Seltzer T and Dittmore SW. Down, Set, Frame: Second-Level Agenda Building and the NFL Network Carriage Dispute. International Journal of Sport Communication. 2009;2(3):340-359. Available from: https://dx.doi.org/10.1123/ijsc.2.3.340.

13) Wirth W, Matthes J, Schemer C, Wettstein M, Friemel T, Hänggli R et al. Agenda Building and Setting in a Referendum Campaign: Investigating the Flow of Arguments among Campaigners, the Media, and the Public. Journalism \& Mass Communication Quarterly. 2010;87(2):328-345. Available from: https://dx.doi.org/10.1177/107769901008700207.

14) Zhang C, Meadows I and Cw. International coverage, foreign policy, and national image: Exploring the complexities of media coverage, public opinion, and presidential agenda. International Journal of Communication. 2012;6:76-95.

15) Guo L and Mccombs M. A third level of media effects. In: Annual conference of the International Communication Association. Boston, MA . 2011,.

16) Guo L and Mccombs M. Toward the third level of agenda setting theory: A network agenda setting model. annual convention of the Association for Education in. Journalism \& Mass Communication St Louis, Missouri . 2011,.

17) Guo L. The application of social network analysis in agenda setting research: A methodological exploration. Journal of Broadcasting \& Electronic Media. 2012;56(4):616-647.

18) Vargo CJ, Guo L, McCombs M and Shaw DL. Network Issue Agendas on Twitter During the 2012 U.S. Presidential Election. Journal of Communication. 2014;64(2):296-316. Available from: https://dx.doi.org/10.1111/jcom.12089.

19) Vu HT, Guo L and McCombs ME. Exploring "the World Outside and the Pictures in Our Heads". Journalism \& Mass Communication Quarterly. 2014;91:669-686. Available from: https://dx.doi.org/10.1177/1077699014550090.

20) Cheng $Y$ and Chan CM. The third level of agenda setting in contemporary China: Tracking descriptions of moral and national education (MNE) in media coverage and people's minds. International journal of Communication. 2015;9:1090-107.

21) Gandy OH. Beyond agenda setting: Information subsidies and public policy. New Jersey. Ablex Publishing Corporation . 1982,.

22) Berkowitz D and Adams DB. Information Subsidy and Agenda-Building in Local Television News. Journalism Quarterly. 1990;67(4):723-731. Available from: https://dx.doi.org/10.1177/107769909006700426.

23) Lang GE and Watergate LK. An exploration of the agenda-building process. In: C W and D B, editors. Mass Communication Review Yearbook. 2. Beverly Hills. Sage Publishers . 1991,. p. 447-68. 
24) Akpabio E. Towards a Public Relations' Agenda Setting Theory. Journal of Social Sciences. 2005;11(3):173-176. Available from: https://dx.doi.org/10. 1080/09718923.2005.11892510.

25) Kiousis S, Laskin A and Kim JY. Congressional agenda-building: examining the influence of congressional communications from the speaker of the House. Public Relations Journal. 2011;5(1):1-14.

26) Saffer A. Intermedia agenda building of the blogosphere: Public relations role in the network . 2013,. Available from: http://wwwinstituteforprorg/ intermedia-agenda-building-of-the-blogoshpere-publicrelations-role-in-the-network.2013.

27) Sciarini $\mathrm{P}$ and Tresch A. Does partisan politics matter? Moderators of the media's agenda-setting power in Switzerland . 2013,. Available from: http: //ecpr.eu/filestore/paperproposal/07691d32-ca58-4d05-96fb-ea3ebad32aaf.pdf.

28) Parmelee JH. The agenda-building function of political tweets. New Media \& Society. 2014;16(3):434-450. Available from: https://dx.doi.org/10.1177/ 1461444813487955.

29) Kiousis S, Kim JY, Ragas M, Wheat G, Kochhar S, Svensson E et al. Exploring New Frontiers of Agenda Building During the 2012 US Presidential Election Pre-Convention Period. Journalism Studies. 2015;16(3):363-382. Available from: https://dx.doi.org/10.1080/1461670x.2014.906930.

30) Riaz S. The Relationship between the Public and Print Media Agendas on National Issues in Pakistan (A Study of the Agenda Setting Role of Print Media in Pakistan . 2009,.

31) Mahsud N, Hassan S, Yaser N and Ishtiaq T. Private Channels' Coverage to NRO and Viewers' Perceptions. Berkeley Journal of Social Sciences. 2011;1(10).

32) M J. Print Media On Coverage of Political Parties in Pakistan: Treatment of Opinion Pages of The 'Dawn'and 'News'. Gomal University Journal of Research. 2013;29(1):118-146.

33) Raza SH and Awan SM. Discourse Analysis of Coverage Regarding Drone Attacks: A study of Pakistani Print Media. Pakistan Journal of Social Sciences (PJSS). 2013;33(2):379-88.

34) Ambreen Q. Representation of Religious Minorities in Pakistani Print Media: a study of Daily Dawn, the News and the Nation. American International Journal of Contemporary Research. 2014;4(1):140-56.

35) Yousaf Z, Zia A and E A. Portrayal of Pak-China Relations in Elite Press of Pakistan, China, India and the United States. Middle-East Journal of Scientific Research. 2014;22(6):870-878.

36) Pakistan G. he New Tide of Voter Turn-out: Report on Voter Turn-out in Pakistan's National Election: 2013 . 2013,. Available from: http://gallup.com.pk/ election/Report1.pdf.

37) European Union . 2013, Available from: http://www.eueom.eu/files/dmfile/eom-pakistan-preliminary-statement- 13052013-en.pdf.

38) Shafiq M, Sultana R and Munir M. Political Rhetoric; Slogan Politics in Pakistan and Role of Parliament. FWU Journal of Social Sciences. 2017;11(2):26-38.

39) Commission I. Final Report of the General Elections-2013 . 2013,. Available from: www.molaw.gov.pk.

40) Shah KM, Shareen S, General P and Oberver Research Foundaation. Pakistan General Elections 2018: Analysis of Results and Implications . 2018,. Available from: https://www.orfonline.org/research/pakistan-general-elections-2018-analysis-of-results-and-implications-46324/.

41) Mcnair B. An introduction to political communication. vol. 5. New York: Routledge . 2011,.

42) Cremonesi C and Salvati E. Populism and the 2014 European Elections: A Comparative Study of Party Speeches by the Leaders of Movimento Cinque Stelle and United Kingdom Independence Party. Journal of Comparative Politics. 2019;12(2):18-37.

43) McCombes M, Lopez-Escobar E and Llamas JP. Setting the Agenda of Attributes in the 1996 Spanish General Election. Journal of Communication. 2000;50(2):77-92. Available from: https://dx.doi.org/10.1111/j.1460-2466.2000.tb02842.x. Doi:10.1111/j.1460-2466.2000.tb02842.x

44) Nisbet MC, Price S, Pascual-Ferra P and Maibach E. Communicating the public health relevance of climate change: A news agenda building analysis. Science Communication. 2010;.

45) Weaver D, Mccombs M and Shaw DL. Agenda-setting research: Issues, attributes, and influences. LL K, editor. Mahwah, NJ: Lawrence Erlbaum Ass . 2004,. Available from: https://books.google.com.pk/books?hl=en\&lr=\&id=2q.

46) Shoemaker P and Reese S. Mediating the Message: Theories of Influences on Mass Media Content. New York. Longman Publishers . 1996,.

47) Holsti OR. Content analysis for the social sciences and humanities. Boston. Addison-Wesley . 1969,.

48) Kiousis S and Wu X. International Agenda-Building and Agenda-Setting. International Communication Gazette. 2008;70:58-75. Available from: https: //dx.doi.org/10.1177/1748048507084578.

49) Robinson KT. News Values and Information Subsidies: How Organizations Build the Agenda on Social and Traditional Media . 2014,. Available from: https://vtechworks.lib.vt.edu/handle/10919/48964. 